\title{
Profil Prostate Spesific Antigen (PSA) pada Penyakit Prostat di Rumah Sakit Umum Daerah Cengkareng Jakarta Barat
}

\author{
Nungki Septi Wulansari ${ }^{1}$, Mieke Marindawati ${ }^{2}$ \\ 1) Program Studi Kedokteran, Fakultas Kedokteran, Universitas Muhammadiyah Jakarta \\ 2) Departemen Patologi Anatomi, Fakultas Kedokteran dan Kesehatan, Universitas Muhammadiyah Jakarta \\ *nungkisepti99@gmail.com
}

\begin{abstract}
Background: prostate cancer is the most common malignancy and cause of death in men in Western countries. In Indonesia prostate cancer ranks 3rd most cancers in men in 2014. Purposes: the purpose of this study was to determine the profile of PSA levels in patients with prostate disease in Cengkareng Regional Hospital in West Jakarta from January 2016 August 2019. Methods: the design of this study used a cross sectional design Descriptive research type collects secondary data of prostate disease patients, prostatitis, prostatic hyperplasia (BPH), prostate cancer, BPH with prostatitis. Results: the results of the study at West Jakarta Cengkareng Regional Hospital in January 2016 - August 2019 showed 190 patients with prostate disease. Patients suffering from prostate disorders with PSA above normal (> $4 \mathrm{ng} / \mathrm{ml}$ ) were $139(73 \%)$ patients. While also found patients with prostate disease who have a normal PSA ( $\leq 4 \mathrm{ng} / \mathrm{ml})$ that is as many as 51 (27\%) patients. Conclusion: prostate abnormalities can occur in patients who have normal PSA $(\leq 4 \mathrm{ng} / \mathrm{ml})$ and above normal (> $4 \mathrm{ng} / \mathrm{ml})$, with the age of the occurrence of prostate abnormalities is 50-93 years.
\end{abstract}

Keywords: Prostate Specific Antigen (PSA), Prostatitis, Benign Prostatic Hyperplasia (BPH), Prostate Cancer, Age.

\begin{abstract}
ABSTRAK
Latar belakang: kanker prostat adalah keganasan tersering dan penyebab kematian pria di negara Barat. Di Indonesia kanker prostat berada di urutan ke-3 kanker terbanyak pada lakilaki tahun 2014. Tujuan: tujuan dari penelitian ini adalah untuk mengetahui profil kadar PSA pada pasien yang terkena penyakit prostat di RSUD Cengkareng Jakarta Barat periode Januari 2016 - Agustus 2019. Metode: desain penelitian ini menggunakan desain cross sectional jenis penelitian deskriptif mengumpulkan data sekunder pasien penyakit prostat, prostatitis, Benign Hyperplasia Prostat (BPH), kanker prostat, BPH dengan prostatitis. Hasil: hasil penelitian di RSUD Cengkareng Jakarta Barat periode Januari 2016 - Agustus 2019 didapatkan pasien dengan penyakit prostat sebanyak 190 pasien. Pasien yang menderita kelainan prostat dengan PSA diatas normal (>4 ng/ml) sebanyak 139 (73\%) pasien. Sedangkan didapatkan pula pasien dengan dengan penyakit prostat yang mempunyai PSA normal $(\leq 4 \mathrm{ng} / \mathrm{mL})$ yaitu sebanyak $51(27 \%)$ pasien. Kesimpulan: kelainan prostat dapat terjadi pada pasien yang mempunyai nilai PSA normal $(\leq 4 \mathrm{ng} / \mathrm{mL})$ dan lebih dari normal $(>4$ $\mathrm{ng} / \mathrm{ml}$ ), dengan usia terjadinya kelainan prostat tersebut adalah $50-93$ tahun.
\end{abstract}


Kata kunci: Prostate Spesific Antigen (PSA), prostatitis, Benign Hyperplasia Prostat (BPH), kanker prostat, usia.

\section{PENDAHULUAN}

Kanker prostat adalah penyakit keganasan yang tersering dan merupakan penyebab kematian, kanker yang menyerang lakilaki menyebabkan 94.000 kematian di Eropa pada 2008 dan lebih dari 28.000 kematian di Amerika Serikat pada tahun 2012. Di Asia, insiden kanker prostat ratarata adalah 7,2 per 100.000 pria per-tahun. Data di Amerika Serikat menunjukkan bahwa $>90 \%$ Kanker prostat ditemukan pada stadium dini dan regional, dengan angka kesintasan (Survival rate) 5 tahun mendekati $100 \%$ (1).

Kanker prostat merupakan kanker yang sering terjadi pada laki-laki tua yang berumur antara 65 tahun sampai 75 tahun (2). Di Indonesia kanker prostat berada di urutan ke-3 kanker terbanyak (9033 kasus baru) dan merupakan penyebab kematian ke-5 (6842 kasus) pada laki-laki pada tahun 2014 (3).

Deteksi dini kanker kelenjar prostat dapat dibedakan berdasarkan faktor resikonya, yaitu pria yang berusia $>50$ tahun dianjurkan melakukan pemeriksaan PSA total (Prostate Specific Antigen) dan pemeriksaan Digital Rectal Examination (DRE) atau colok dubur setiap tahunnya. Bila ada keluarga yang menderita kanker kelenjar prostat, skrining dianjurkan sejak usia 40 tahun. Tetapi, PSA memiliki keterbatasan sebagai alat diagnostik yaitu kadar PSA dapat meningkat pada penyakit kelenjar prostat yang jinak ataupun ganas (4). Pemeriksaan PSA digunakan untuk diagnosis kanker prostat, tetapi sebagaimana akan diuraikan, juga mempunyai sejumlah keterbatasan. PSA ialah hasil dari epitel prostat dan pada keadaan normal disekresi dalam semen. PSA adalah suatu protease serin yang berfungsi untuk memecah dan mencairkan gumpalan semen yang terbentuk setelah ejakulasi (2).

Satu keterbatasan PSA adalah meskipun PSA spesifik organ tetapi PSA tidak spesifik kanker. Benign Prostatic Hyperplasia (BPH), prostatitis, infark prostat. Pengujian PSA serum berguna tetapi merupakan tes skrining kanker yang tidak pasti, dengan hasil negatif-palsu dan positif-palsu yang bermakna (2).

Tujuan dari penelitian ini adalah untuk mengetahui peningkatan PSA pada penyakit prostat, melihat insiden pada penyakit prostat, melihat penyakit prostat yang mempuyai nilai PSA diatas normal, melihat penyakit prostat yang mempunyai nilai PSA normal, dan untuk melihat usia pasien yang terkena penyakit prostat.

\section{METODE}

Penelitian ini menggunakan desain penelitian cross sectional, serta menggunakan data sekunder dari rekam medik pasien, dengan rancangan penelitian deskriptif. Penelitian ini dilakukan di Rumah Sakit Umum Daerah Cengkareng Jakarta Barat pada bulan November 2019. Populasi dalam penelitian ini adalah semua pasien yang populasi yang diambil dari data sekunder atau Rekam Medik pasien yang terdiagnosis penyakit prostat dalam periode waktu Januari 2016 - Agustus 2019 yang terdapat di RSUD Cengkareng, Jakarta Barat. Sampel adalah bagian populasi yang akan diteliti atau sebagian 
jumlah dari populasi. Teknik pengambilan sampel mengunakan total sampling yaitu sebanyak 190 pasien. Penelitian ini telah lolos persetujuan etik dengan nomor: 092/PE/KE/FKK-UMJ/X/2019 yang dikeluarkan oleh Komisi Etik Penelitian Kesehatan Fakultas Kedokteran dan Kesehatan UMJ.

\section{HASIL}

Berdasarkan Tabel 1 yang telah disajikan di atas, jumlah pasien dengan penyakit prostat di RSUD Cengkareng Januari 2016 - Agustus 2019 yang mempunyai nilai PSA normal $(\leq 4 \mathrm{ng} / \mathrm{mL})$ adalah sebanyak 51 pasien $(27 \%)$, yang terdiri atas $1(50 \%)$ pasien prostatitis, $44(30 \%)$ pasien $\mathrm{BPH}, 2$ (25\%) pasien kanker prostat, $4(11 \%)$ pasien BPH dengan prostatitis. Sedangkan Pasien yang mempunyai nilai PSA diatas normal (>4 ng/ml) sebanyak 139 (73\%), terdiri atas $1(50 \%)$ pasien prostatitis, $101(70 \%)$ pasien $\mathrm{BPH}, 6(75 \%)$ pasien kanker prostat, $31(89 \%)$ pasien $\mathrm{BPH}$ dengan prostatitis.

Tabel 1. Profil Prostate Spesific Antigen (PSA) pada penyakit prostat di RSUD Cengkareng Januari 2016 Agustus 2019

\begin{tabular}{lccc}
\multicolumn{4}{c}{ Agustus 2019 } \\
$\begin{array}{lccc}\text { Penyakit } \\
\text { Prostat }\end{array}$ & $\begin{array}{c}\text { Normal PSA } \\
\mathrm{ng} / \mathrm{ml}) \\
(\mathrm{n}=51)\end{array}$ & $\begin{array}{c}\text { Nilai PSA } \\
\text { diatas } \\
\text { Normal }(4 \\
\mathrm{ng} / \mathrm{ml})\end{array}$ & $\begin{array}{c}\text { Jumlah } \\
\text { Pasien } \\
(\mathrm{n}=139)\end{array}$ \\
\hline Prostatitis & $1(50 \%)$ & $1(50 \%)$ & $2(2 \%)$ \\
BPH & $44(30 \%)$ & $101(70 \%)$ & $145(76 \%)$ \\
Kanker Prostat & $2(25 \%)$ & $6(75 \%)$ & $8(3 \%)$ \\
BPH dengan & $4(11 \%)$ & $31(89 \%)$ & $35(18 \%)$ \\
Prostatitis & $51(100 \%)$ & $139(100 \%)$ & $190(100 \%)$ \\
\hline
\end{tabular}

Tabel 2. Pasien dengan Penyakit Prostat berdasarkan usia yang terdapat di RSUD Cengkareng Januari 2016 Agustus 2019

\begin{tabular}{cccccc}
\hline $\begin{array}{c}\text { Usia } \\
\text { (Tahun) }\end{array}$ & Prostatitis & BPH & $\begin{array}{c}\text { Kanker } \\
\text { Prostat }\end{array}$ & $\begin{array}{c}\text { BPH } \\
\text { dengan } \\
\text { Prostatitis }\end{array}$ & Pasien \\
\hline $50-60$ & 0 & 22 & 0 & 6 & $\begin{array}{c}28 \\
(15 \%) \\
61-70\end{array}$ \\
\hline
\end{tabular}

\begin{tabular}{|c|c|c|c|c|c|}
\hline & & & & & $(37 \%)$ \\
\hline $71-80$ & 2 & 59 & 2 & 8 & $\begin{array}{c}79 \\
(73 \%)\end{array}$ \\
\hline $81-93$ & 0 & 11 & 2 & 7 & $\begin{array}{c}20 \\
(11 \%)\end{array}$ \\
\hline Jumlah & 2 & 145 & 8 & 35 & 190 \\
\hline
\end{tabular}

Pada Tabel 2 menunjukkan berdasarkan usia terdapat 190 pasien dengan penyakit prostat. Pasien yang termuda yang terkena penyakit prostat adalah pasien yang berusia 50 tahun, sedangkan pasien yang tertua yang terkena penyakit prostat berusia 93 tahun. Pada usia pasien 50-60 tahun menunjukan 28 $(15 \%)$ pasien terkena penyakit prostat yang terdiri dari 22 pasien terkena BPH, 6 pasien terkena BPH dengan Prostatitis. Pada usia 61-70 tahun terdapat 71 (37\%) pasien terkena penyakit prostat yang terdiri dari 53 pasien terkena $\mathrm{BPH}, 4$ pasien terkena kanker prostat, 14 pasien terkena BPH dengan Prostatitis. Pada usia 71-80 tahun pasien yang terkena penyakit prostat sebanyak $71(37 \%)$ pasien yang terdiri dari 2 pasien terkena prostatitis, 59 pasien terkena BPH, 2 pasien terkena kanker prostat, 8 pasien terkena $\mathrm{BPH}$ dengan Prostatitis. Pada usia 80-93 tahun pasien yang terkena penyakit prostat sebanyak 20 (11\%) yang terdiri dari 11 pasien terkena BPH, 2 pasien terkena kanker prostat, 7 pasien terkena BPH dengan prostatitis.

\section{PEMBAHASAN}

Nilai normal PSA adalah $(\leq 4 \mathrm{ng} / \mathrm{mL})$ $(1,4,5)$. Jumlah pasien yang mempunyai nilai PSA diatas normal adalah sebanyak $139(73 \%)$, terdiri atas $1(50 \%)$ pasien prostatitis, 101(70\%) pasien $\mathrm{BPH}, 6(75 \%)$ pasien kanker prostat, 31(89\%) pasien BPH dengan prostatitis. Hal ini didukung oleh penelitian Tjandra F pada tahun 20132015 di RSUP Prof. Dr. R. D. Kandou Manado yang menyebutkan bahwa kadar PSA dari 54 sampel dapat dilihat frekuensi 
tertinggi terdapat pada PSA diatas normal (5).

Pada penelitian ini ditemukan pula pasien yang terkena penyakit prostat dengan PSA dibawah normal sebanyak 51 pasien $(27 \%)$, yang terdiri atas $1(50 \%)$ pasien prostatitis, $44(30 \%)$ pasien $\mathrm{BPH}, 2$ (25\%) pasien kanker prostat, 4 (11\%) pasien BPH dengan prostatitis. Hal ini selaras dengan penelitian sebelumnya yang telah dilakukan oleh Thompson I dkk bahwa ditemukan 6 sampel kanker prostat yang diperoleh dari 10 pasien yang mempunyai PSA normal $(4,0 \mathrm{ng} / \mathrm{mL}$ atau kurang). Dengan jumlah pasien kanker prostat $10,1 \%$ dengan kadar PSA 0,6-1,0 $\mathrm{ng} / \mathrm{mL}$ dan naik jumlah pasiennya menjadi 26,9\% dengan PSA berkisar antara 3,1 4,0 ng/mL. Dengan hal ini tidak dapat dipastikan bahwa seorang yang mempunyai nilai PSA normal tidak memiliki risiko kanker prostat (6).

Suatu keterbatasan PSA ialah meskipun spesifik-organ tetapi tidak spesifik-kanker, $\mathrm{BPH}$, prostatitis, infark prostat. Instrumentasi untuk pemeriksaan prostat dan ejakulasi juga meningkatkan kadar PSA serum. Sebaliknya, 20\% sampai $40 \%$ penderita kanker prostat mempunyai kadar PSA $4 \mathrm{ng} / \mathrm{mL}$ atau kurang (2). Hal ini selaras dengan penelitian yang dilakukan peneliti di RSUD Cengkareng yaitu terdapat pasien dengan diagnosis kanker prostat dengan PSA dibawah normal $(\leq 4 \mathrm{ng} / \mathrm{mL})$.

Dari tabel 2 dapat dilihat dari 190 pasien yang memiliki rentan usia yang tidak terlalu bervariasi. Pada pasien yang berusia 50 - 60 pasien yang terkena penyakit prostat sebanyak $28(15 \%)$ yang terdiri dari 22 pasien terkena BPH, 6 pasien terkena BPH dengan prostatitis. Pada usia 61-70 tahun terdapat 71 (37\%) pasien yang terkena penyakit prostat, yang terdiri dari 55 pasien terkena $\mathrm{BPH}, 4$ pasien terkena kanker prostat, 14 pasien terkena BPH dengan Prostatitis. Usia 7180 tahun pasien yang terkena penyakit prostat sebanyak 71 (37\%) pasien yang terdiri dari 2 pasien terkena prostatitis, 59 pasien terkena $\mathrm{BPH}, 2$ pasien terkena kanker prostat, 8 pasien terkena $\mathrm{BPH}$ dengan prostatitis. Usia 81-93 tahun terdapat $20(11 \%)$ pasien terkena penyakit prostat yang terdiri dari 11 pasien terkena $\mathrm{BPH}, 2$ pasien terkena kanker prostat, 7 pasien terkena BPH dengan prostatitis. Hal ini didukung oleh penelitian yang dilakukan oleh Valdo R. Solang, Alwin Monoarfa dan pada tahun 2013-2015 di RSUP Prof. Dr. R. D. Kandou Manado yang menyebutkan bahwa terdapat 54 pasien dengan diagnosis kanker prostat dan kelompok usia terbanyak ialah usia 61-70 tahun sebanyak 20 kasus $(37,0 \%)$ diikuti usia 71-80 tahun sebanyak 18 kasus $(33,3 \%)$ dan yang paling sedikit $<51$ tahun sebanyak 1 kasus (1,8\%).6 Umumnya kanker prostat mengenai pria dewasa tua dengan puncak pada umur 65-75 tahun (7).

\section{KESIMPULAN}

Insiden Penyakit Prostat yang terdiri dari Prostatitis, BPH (Benign Hyperplasia Prostat), Kanker Prostat di RSUD Cengkareng pada Januari 2016 - Agustus 2019 sebanyak 190 pasien, Pasien yang mempunyai nilai PSA diatas normal adalah sebanyak 139 (73\%), terdiri atas 1 $(50 \%)$ pasien prostatitis, 101(70\%) pasien $\mathrm{BPH}, 6(75 \%)$ pasien kanker prostat, $31(89 \%)$ pasien BPH dengan prostatitis, Pasien yang terkena penyakit prostat dengan PSA dibawah normal sebanyak 51 pasien $(27 \%)$, yang terdiri atas $1(50 \%)$ pasien prostatitis, $44(30 \%)$ pasien $\mathrm{BPH}, 2$ $(25 \%)$ pasien kanker prostat, $4(11 \%)$ pasien $\mathrm{BPH}$ dengan prostatitis.Pada pasien 
yang berusia 50 - 60 pasien yang terkena penyakit prostat sebanyak 28 (15\%) pasien. Usia 61-70 tahun terdapat 71 (37\%) pasien yang terkena penyakit prostat. Usia 71-80 tahun pasien yang terkena penyakit prostat sebanyak 71 (37\%) pasien. Usia 81-93 tahun terdapat $20(11 \%)$ pasien terkena penyakit prostat.

\section{UCAPAN TERIMAKASIH}

Terimakasih kepada keluarga besar penulis, almamater Universitas Muhammadiyah Jakarta dan RSUD Cengkareng yang telah memberikan kesempatan kepada penulis untuk meneliti penelitian ini.

\section{KONFLIK KEPENTINGAN}

Penulis tidak ada konflik kepentingan dan tidak ada koneksi dengan organisasi apapun yang dapat menimbulkan bias pada hasil penelitian.

\section{REFERENSI}

1. Komite Penanggulangan Kanker Nasional. Panduan Pelaksanaan Kanker Paru. Jakarta: Kementerian Kesehatan Republik Indonesia; 2016. p. 43.

2. Kumar V, Abdul K, Abbas CJ. Buku Ajar Patologi Robbins. 9th ed. Singapura: Elsevier; 2013. 655-659 p.

3. Syafiie SHN. Hubungan Antara Tumor Associated- Macrophages (TAMs), Microvessel Density (MVD), Kadar Prostatic Specific Antigen (PSA) dengan Derajat Histologis Lesi Prostat Pin High Grade dan Adenokarsinoma Prostat. Fakultas Kedokteran Universitas Gajah Mada; 2015.

4. Thristy I. Prostat Spesifik Antigen. Bul Farmatera.
2016;3(September):14-6.

5. Myh E, Umbas R, Mochtar CA, Santoso RB. Prostate Specific Antigen (PSA) Inisial $\geq 100 \mathrm{ng} / \mathrm{ml}$ Menggambarkan Stadium Lanjut dan Rendahnya Survival Kanker Prostat. Indones J Cancer. 2011;5(2):7-10.

6. Solang VR, Monoarfa A, Tjandra F. Profil penderita kanker prostat di RSUP Prof. Dr. R. D. Kandou Manado periode tahun 2013-2015. J e-Clinic. 2016;4(2).

7. Komite Penanggulangan Kanker Nasional. Kanker Prostat. Panduan Penatalaksanaan Kanker Prostat. Kementrian Kesehatan Republik Indonesia; 2015. 